\title{
Pengembangan Aplikasi Multimedia Pembelajaran CD \\ Tutorial Pada Mata Kuliah Berbasis Praktik
}

\author{
Rizqi Abdillah ${ }^{16}$, Sunardi ${ }^{17}$, Deny Tri Ardianto ${ }^{18}$ \\ rizqiabdillah1992@gmail.com
}

\begin{abstract}
The purpose of this research is to describe the needs of students to the application of $C D$ tutotial as learning media at the course based on practice, its developing and the students' responds towards the media used in the instructional process. The program of Educational Technology is famous of its students who have a high capability in multimedia field of study as some of the courses relate to technology-based learning. Unfortunatelly, there are some obstacles coming up as the practice-based course has less optimum on its real class. It makes the researcher trying to develop an application of learning media in term of $C D$ Tutorial to be applied at the class by the practice-based course. This research uses ADDIE developing model (Analysis, Design, Development, Implementation, Evaluation). The result of this research and development will be in term of media product which is later on will be done some evaluation tests from the expert teams, and at last filed test to know its effectiveness of its media on the instructional process.
\end{abstract}

Key words: Multimedia application,; CD tutorial; educational technology.

\footnotetext{
${ }^{16}$ Mahasiswa Magister Teknologi Pendidikan Universitas Sebelas Maret Surakarta

17 Dosen Universitas Sebelas Maret Surakarta

18 Dosen Universitas Sebelas Maret Surakarta
} 


\section{PENDAHULUAN}

Deningkatan kualitas pendidikan untuk menghasilkan lulusan yang berkualitas dan unggul merupakan tuntutan yang tidak terelakkan untuk mengikuti perkembangan ilmu pengetahuan dan teknologi yang tidak pernah berhenti. Perguruan Tinggi khususnya Lembaga Pendidikan Tenaga Kependidikan (LPTK) mempunyai kewajiban untuk menyiapkan lulusannya menjadi tenaga yang profesional sesuai dengan standar lulusan yang dapat diterima secara global pada dunia kerja.

Secara umum Program Studi Magister Teknologi Pendidikan di UNS ini bertujuan menghasilkan lulusan yang memiliki kompetensi dalam bidang teknologi pendidikan dengan kemampuan untuk menjadi pendidik, peneliti dan pengembang/tenaga ahli yang berkualifikasi teknologi pendidikan dan pengelola satuan pendidikan/latihan. Melihat tujuan dari program studi ini, mahasiswa lulusan Teknologi Pendidikan setidaknya memiliki dua keahlian. Pertama, lulusan Teknologi Pendidikan dapat menjadi seorang school media specialist alias ahli media pembelajaran. Fungsinya adalah membantu sekolah mengoptimalkan mutu pembelajaran dengan mengembangkan (analisis, desain, pengembangan, pemanfaatan, pengelolaan, evaluasi media pembelajaran dan sumber-sumber belajar yang tepat). Kedua, lulusan Teknologi Pendidikan dapat menjadi seorang instructional system designer alias ahli desain sistem pembelajaran. Keduanya, sebenarnya bisa bekerja di persekolahan maupun nonpersekolahan seperti lembaga diklat, perusahaan, dan isntitusi lain.

Mata kuliah pada Program Studi Teknologi Pendidikan yang diberikan berupa teori dan praktik dengan maksud memberikan kualitas pengetahuan dan kemampuan kepada mahasiswa, total ada 21 mata kuliah yang diajarkan selama kurun dua semester. Proses pembelajaran perkuliahan pada program studi ini dengan tuntutan kompetensi lulusan yang diharapkan masih belum terlaksana secara optimal. Pada umumnya semua strategi pembelajaran dalam perkuliahan yang digunakan masih kurang variatif, metode ceramah dan presentasi pada setiap pembahasan materi masih dominan. Hal ini tentu menimbulkan kejenuhan dalam proses belajar mahasiswa yang terlalu monoton, tidak ada mix metode pembelajaran yang diterapkan, serta pada beberapa mata kuliah yang basisnya praktik masih belum didukungnya sarana prasarana dalam pembelajaran yang menjadi salah satu hambatan mengoptimalkannya proses belajar, Program studi Teknologi Pendidikan merupakan program studi yang menerima mahasiswa dengan berbagai disiplin ilmu, hal ini juga menjadi penghambat dalam pembelajaran dengan materi perkuliahan yang dianggap baru dalam bidangnya.

Dalam hal ini penulis mengambil 1 dari 21 mata kuliah yang dijadikan sampel penelitian. Penulis lebih menyoroti pada mata kuliah yang membentuk kemampuan atau ketrampilan pada mahasiswa, ada 3 mata kuliah yang basisnya berupa praktik yaitu mata kuliah Workshop dan Pemanfaatan Media, Online Learning dan E- Learning, Pengembangan Bahan Ajar. Dari ketiga mata kuliah tersebut diambil sampel satu yaitu mata kuliah Workshop dan Pemanfaatan Media. Mata kuliah ini merupakan salah satu mata kuliah yang diajarkan untuk mahasiswa teknologi pendidikan UNS pada semseter kedua, selama satu semester ada dua materi yang diajarkan yakni audio video dan e-book berbasis epup. Penulis lebih melihat pada pembelajaran audio video karena materinya lebih kompleks, pada pembelajaran ini kompetensi mahasiswa diharapkan antara lain; memahami proses pembuatan video pembelajaran dari awal, proses, hingga akhir; memahami teknik pengambilan gambar atau video dengan benar; mahasiswa memiliki hard and soft skill terkait media pembelajaran berbasis digital khususnya media video pembelajaran.

Melihat perkembangan dunia teknologi dan informasi dewasa ini terjadi begitu pesat pada berbagai aspek kehidupan manusia saat ini, tak terkecuali dalam dunia pendidikan ditandai dengan 
munculnya media atau aplikasi pembelajaran yang sangat membantu dalam proses pembelajaran. Beragam bentuk media atau aplikasi tersebut berupa; internet, buku elektronik (E-book), Slide Presentasi (PowerPoint), serta CD tutorial. Adapun format dari berbagai media atau aplikasi digolongkan menjadi 5 klasifikasi yaitu 1) tutorial, sebagai tutor siswa dalam belajar; 2) latihan dan pengulangan (drill and practice) untuk membantu siswa memahami pelajaran yang dipelajari sebelumnya; 3) simulasi, memberikan gambaran atau model dari peristiwa; 4) games, memberikan kesempatan menggunakan pengetahuan yang baru dipelajari; 5) percobaan atau eksperimen, percobaan ini mirip dengan format simulasi, namun lebih ditunjukan pada kegiatan yang bersifat eksperimen. (Warsita, 2008).

Dalam penelitian ini langkah yang akan diambil guna meningkatkan pemahaman mahasiswa adalah dengan cara perbaikan proses pengajaran melalui multimedia pembelajaran dengan bentuk $C D$ tutorial. Compact Disk (CD) Tutorial adalah sebuah pembelajaran yang melalui sebuah film dan gambar animasi yang didalamnya merupakan materi dari sebuah buku yang dikemas dengan baik, menarik, dan mampu mengajak interaksi dari peserta didik. Adobe Flash Professional CS6 dialternatifkan sebagai salah satu software pembuat media pembelajaran karena dalam penggunaan software (perangkat lunak) ini dipadukan berbagai media baik teks, gambar, audio, video dan animasi yang dikemas menjadi produk multimedia untuk mencapai tujuan (pembelajaran) tertentu.

Berdasarkan uraian di atas, perlu dilakukan upaya (penelitian dan pengembangan) untuk membantu meningkatkan pemahaman mahasiswa dalam proses pembelajaran pada mata kuliah Workshop dan Pemanfaatan Media pada khususnya dan untuk mata kuliah berbasis praktik yang lain pada umumnya. Dalam jurnal ini yang akan dibahas adalah bagaimana kebutuhan mahasiswa dalam mata kuliah berbasis praktik dan bagaimana penerapan aplikasi multimedia pembelajaran berbasis $C D$ tutorial dalam pembelajaran Workshop dan Pemanfaatan Media.

Kata media berasal dari bahasa Latin dan merupakan bentuk jamak dari kata medium yang secara harfiah berarti perantara atau pengantar (Sadiman, 2009). Media adalah perantara atau pengantar pesan dari si pengirim (komunikator atau sumber) kepada si penerima (komunikan). Jika diartikan secara luas media adalah segala sesuatu yang dapat digunakan untuk menyalurkan pesan dari pengirim ke penerima sehingga dapat merangsang pikiran, perasaan, perhatian, minat serta perhatian siswa sedemikian rupa sehingga proses belajar terjadi (Sadiman, 2009).

Apabila media itu membawa pesan-pesan atau informasi yang bertujuan pembelajaran atau maksud-maksud pembelajaran maka media itu disebut media pembelajaran. Dapat disimpulkan bahwa media pembelajaran adalah alat yang dapat membantu proses belajar mengajar dan juga berfungsi untuk memperjelas makna pesan yang disampaikan, sehingga dapat mencapai tujuan pembelajaran dengan baik dan sempurna (Kustandi \& Sutjipto, 2011).

Beberapa pengertian multimedia sebagai berikut: multimedia merupakan kombinasi antara perangkat keras dan perangkat lunak komputer untuk menintegrasikan video, animasi, audio, grafik (Gunawardhana, 2016). Multimedia adalah kombinasi atau perpaduan dari teks, foto, seni grafis, suara, animasi, dan elemen-elemen video yang telah dimanipulasi secara digital (Vaughan, 2006). Multimedia Pembelajaran adalah tipe pembelajaran dimana penyampaiannya menggunakan komputer dengan konteks pembelajaran (teks, grapik, audio, video, animasi, dII) berupa CD-ROM atau file komputer (Rusli, 2014). 
CD ROM (Read Only Memory) merupakan salah satu dari beberapa tempat penyimpan memory berupa suara, video, teks, dan program aplikasi. Manfaat yang dapat diperoleh dari penggunaan media CD Tutorial dalam proses pembelajaran sangat banyak, diantaranya adalah pembelajaran dapat lebih menarik, waktu pelaksanaan pembelajaran dapat diperpendek, proses pembelajaran dapat berlangsung kapanpun dan dimanapun diperlukan, pembelajaran menjadi lebih interaktif, kualitas pembelajaran dapat ditingkatkan, mudah digunakan, dan bisa diputar berulang-ulang.

Sebagai salah satu komponen sistem pembelajaran, pemilihan dan penggunaan multimedia pembelajaran harus memperhatikan karakteristik komponen lain, seperti tujuan, materi, strategi, dan juga evaluasi pembelajaran.

Daryanto (2010) menjabarkan karakteristik pembelajaran multimedia adalah sebagai berikut:

a. Memiliki lebih dari satu media yang konvergen, misalnya menggabungkan unsur audio dengan visual.

b. Bersifat interaktif, dalam pengertian memiliki kemampuan untuk mengakomodasi respon pengguna.

c. Bersifat mandiri, yaitu memberikan kemudahan dan kelengkapan isi sedemikian rupa sehingga pengguna bisa menggunakan tanpa bimbingan dari orang lain.

Selain memenuhi ketiga karakteristik tersebut, multimedia pembelajaran sebaiknya juga memenuhi fungsi sebagai berikut:

a. Mampu memperkuat respon pengguna secepatnya dan sesering mungkin.

b. Mampu memberikan kesempatan pada siswa untuk mengontrol laju kecepatan belajarnya sendiri.

c. Memperhatikan bahwa siswa mengikuti suatu urutan yang jelas dan terkendali.

Mukminan, menjelaskan adanya banyak alasan mengapa siswa menyukai multimedia pembelajaran interaktif sebagaimana dikutip oleh Kustiono (2010), dikarenakan: (1) MPI tidak pernah lelah; (2) MPI tidak pernah putus asa dan marah; (3) MPI memberikan kesempatan pada siswa untuk belajar secara mandiri; (4) MPI tidak pernah lupa mengoreksi dan memuji; (5) MPI menyenangkan dan menghibur; (6) MPI mendukung pembelajaran individual; (7) MPI tidak mempermalukan siswa ketika membuat kesalahan; (8) MPI membuat penelitian dapat dilakukan secara berbeda; (9) MPI mampu memberi umpan balik dengan segera; (10) MPI lebih objektif dibanding dengan guru; (11) MPI melibatkan kegiatan penglihatan, pendengaran, dan sentuhan; (12) MPI menolong siswa memperbaiki ejaan mereka. Dengan demikian, MPI memegang peranan yang penting dan menjadi salah satu alternatif bagi keberhasilan suatu pembelajaran.

\section{METODE PENELITIAN}

Metode yang digunakan adalah penelitian dan pengembangan (R\&D) yakni metode penelitian yang digunakan untuk menghasilkan produk tertentu, dan menguji keefektifan produk tersebut (Sugiyono, 2010). Prosedur pengembangan yang digunakan yaitu model pengembangan ADDIE yang diadopsi oleh Munir (2008). Produk yang dihasilkan berupa CD pembelajaran interaktif yang akan diujikan pada responden penelitian yaitu mahasiswa teknologi pendidikan semester 2 berjumlah 18 mahasiswa.

Tahapan uji coba produk yang dikembangkan meliputi validasi ahli, dan uji coba kelompok besar. Pada implementasi pembelajaran, penerapan produk multimedia dalam pembelajaran untuk 
mengetahui perbandingan pembelajaran yang menggunakan produk $C D$ pembelajaran interaktif dengan pembelajaran yang sama tetapi tidak menggunakan produk CD pembelajaran interaktif. Dalam penelitian yang dilakukan dengan menggunakan desain eksperimen One-Shot Case Study.

\section{HASIL DAN PEMBAHASAN}

Pengembangan $C D$ pembelajaran interaktif ini dilakukan lima tahap sesuai prosedur pengembangan yang digunakan yakni ADDIE (Analisis, Desain, Pengembangan, Implementasi, dan Evaluasi). Penjebarannya sebagai berikut. Contoh tampilan isi dari CD pembelajaran interaktif.

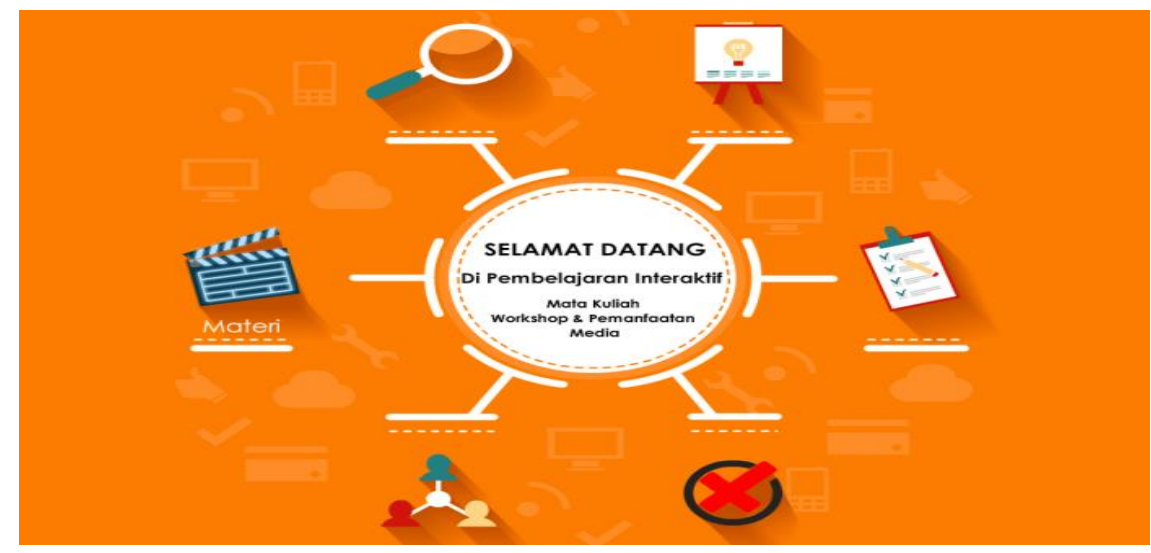

Gambar 1. Menu Tampilan Awal Media

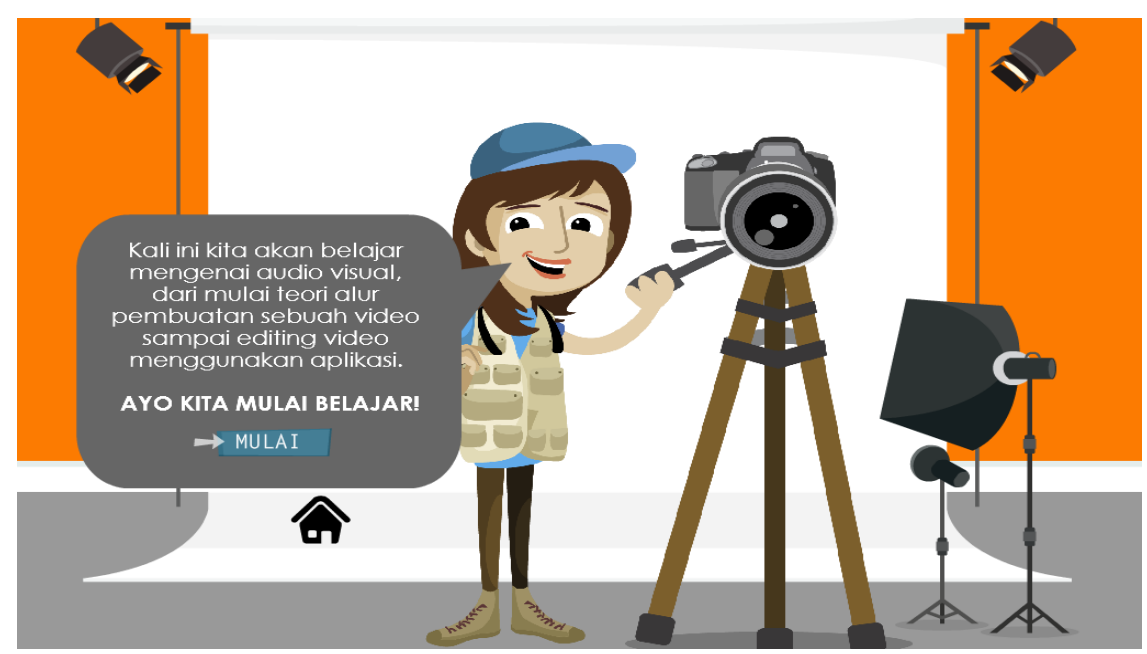

Gambar 2. Menu Tampilan Awal Materi

Setelah produk media jadi, dilakukan pengujian produk yaitu dengan mengevaluasi produk yang telah dikembangkan, tujuannya untuk menguji semua fungsi-fungsi produk, dan mendapatkan validasi tingkat kelayakan produk yang dikembangkan dari ahli media dan ahli materi. 
Tabel 1. Hasil Rekapitulasi Penilaian Ahli Media

\begin{tabular}{|c|c|c|c|c|}
\hline \multirow[t]{2}{*}{ No } & \multirow[t]{2}{*}{ Aspek Penilaian } & \multicolumn{2}{|c|}{$\begin{array}{c}\text { Jumlah Skor Hasil } \\
\text { Penialaian }\end{array}$} & \multirow{2}{*}{$\begin{array}{l}\text { Skor Yang } \\
\text { Diharapkan }\end{array}$} \\
\hline & & Ahli 1 & Ahli 2 & \\
\hline 1 & Kemudahan Navigasi & 24 & 23 & 24 \\
\hline 2 & Kandungan Kognisi & 14 & 14 & 16 \\
\hline 3 & Informasi Presentasi Penilaian & 20 & 19 & 20 \\
\hline 4 & Integrasi Media & 20 & 19 & 20 \\
\hline 5 & Artistik \& Estetika & 38 & 37 & 40 \\
\hline 6 & Fungsi Keseluruhan & 18 & 18 & 20 \\
\hline & Jumlah & 134 & 130 & 140 \\
\hline & Persentase Kelayakan (\%) & $95,7 \%$ & $92,8 \%$ & $\Sigma=94,2 \%$ \\
\hline
\end{tabular}

Penilaian oleh ahli media terhadap produk dikategorikan menjadi 6 aspek penilaian diantaranya adalah kemudahan navigasi, kandungan kognisi, informasi presentasi penilaian, integrasi media, artistik \& estetika, fungsi keseluruhan. secara keseluruhan didapatkan hasil persentase tingkat kelayakan dari produk yang dikembangkan adalah sebesar $94,2 \%$ yang artinya bahwa media yang dikembangkan dikatakan layak sesuai dengan interval persentase tingkat kelayakan produk.

Tabel 2. Hasil rekapitulasi penilaian ahli materi

\begin{tabular}{|c|c|c|c|c|}
\hline No & Aspek Penilaian & $\begin{array}{c}\text { Jumlah Skor } \\
\text { hasil } \\
\text { penialaian }\end{array}$ & $\begin{array}{l}\text { Skor Yang } \\
\text { Diharapkan }\end{array}$ & $\begin{array}{c}\text { Persentase } \\
\text { kelayakan (\%) }\end{array}$ \\
\hline \multirow[t]{4}{*}{1} & Komponen Kelayakan Isi & & & \\
\hline & Cakupan Materi & 18 & 20 & 90 \\
\hline & Keterkaitan Kompetensi/Kurikulum & 10 & 12 & 83.3 \\
\hline & Akurasi Materi & 6 & 8 & 75 \\
\hline \multirow[t]{5}{*}{2} & Komponen Penyajian & & & \\
\hline & Penyajian Pembelajaran & 20 & 20 & 100 \\
\hline & Komunikatif dan Interaktif & 12 & 12 & 100 \\
\hline & Aspek Bahasa & 8 & 8 & 100 \\
\hline & Jumlah & 74 & 80 & $92.5 \%$ \\
\hline
\end{tabular}

Penilaian oleh ahli materi terhadap produk dikategorikan menjadi dua, yaitu mengenai kelayakan isi (cakupan materi, kandungan kognisi, keterkaitan kompetensi dasar/kurikulum, akurasi materi) dan penyajian (penyajian pembelajaran, komunikatif dan interaktif, aspek bahasa). Secara keseluruhan hasil 
penilaian ahli materi mempunyai persentase tingkat kelayakan produk sebesar $92,5 \%$ yang bisa dikatakan sangat layak, sesuai dengan interval persentase tingkat kelayakan produk.

Tabel 3. Hasil Rekapitulasi Uji Kelompok Besar Terhadap Media

\begin{tabular}{clccc}
\hline No & Aspek Penilaian & $\begin{array}{c}\text { Jumlah Skor } \\
\text { hasil } \\
\text { penialaian }\end{array}$ & $\begin{array}{c}\text { Skor Yang } \\
\text { Diharapkan }\end{array}$ & $\begin{array}{c}\text { Persentase } \\
\text { kelayakan } \\
(\%)\end{array}$ \\
\hline $\mathbf{1}$ & Kualitas Penampilan Gambar & 298 & 360 & 82,7 \\
\hline $\mathbf{2}$ & Penyajian Materi & 289 & 360 & 80,3 \\
\hline $\mathbf{3}$ & Interaksi Program & 237 & 288 & 82,3 \\
\hline $\mathbf{4}$ & Interaksi Pengguna & 364 & 432 & 84,3 \\
\hline & Jumlah & 1188 & 1440 & 82,5 \\
\hline
\end{tabular}

Berdasarkan data dari tabel 3 menunjukan bahwa secara keseluruhan hasil penilaian dari uji kelompok besar mempunyai persentase tingkat kelayakan produk sebesar $82,5 \%$ yang bisa dikatakan sangat layak, sesuai dengan interval persentase tingkat kelayakan produk.

Selanjutnya adalah tahap implementasi produk CD pembelajaran interaktif. Tahap ini bertujuan untuk melihat respon mahasiswa dalam pembelajaran dengan membandingkan penerapan $C D$ pembelajaran interaktif dengan pembelajaran yang tidak menggunakan media. Dengan menggunakan metode eksperimen yaitu One-Shot Case Study penelitian yang dilakukan dengan mengambil responden mahasiswa Teknologi Pendidikan semster 2 dengan jumlah 18 mahasiswa. Dengan teknik pengumpulan data angket bentuk cheklist yang terdiri dari 13 butir soal untuk angket yang menggunakan $C D$ Interaktif dan 10 butir soal untuk angket menggunakan $C D$ Interaktif didapatkan hasil sebagai berikut;

Tabel 4. Respon Mahasiswa dalam Pembelajaran

\begin{tabular}{ccccc}
\hline No & Aspek Penilaian & $\begin{array}{c}\text { Jumlah Skor } \\
\text { hasil } \\
\text { penialaian }\end{array}$ & $\begin{array}{c}\text { Skor Yang } \\
\text { Diharapkan }\end{array}$ & $\begin{array}{c}\text { Persentase } \\
\text { kelayakan } \\
\text { (\%) }\end{array}$ \\
\hline $\mathbf{1}$ & Tidak Menggunakan CD interaktif & 700 & 930 & 74,8 \\
\hline $\mathbf{2}$ & Meggunakan CD Interaktif & 580 & 720 & 80,5 \\
\hline
\end{tabular}

Berdasarkan data dari tabel 4 menunjukan perbandingan respon mahasiswa dalam penerapan pembelajaran menggunakan $C D$ pembelajaran interaktif dengan tidak menggunakan media, hasilnya untuk yang menggunakan $C D$ interaktif sebesar $74,8 \%$ dan untuk yang menggunakan $C D$ interaktif 
sebesar $80,5 \%$. Dari hasil tersebut ada peningkatan 5,7\% apabila pembelajaran dilakukan menggunakan $\mathrm{CD}$ pembelajaran interaktif.

Sejalan dengan penelitian yang dilakukan oleh Hashmi (2016), mengenai implementasi multimedia sebagai alat pendidikan EFL, hasilnya menunjukan bahwa penerapan multimedia dan penggunaan internet di kelas EFL menunjukan peningkatan motivasi dan membantu peserta didik dalam mencapai prestasi yang diinginkannya.

Kemudian Malik (2012) juga menegaskan dalam penelitiannya yakni multimedia mengatasi batas ruang dan waktu dan memberikan bukti nyata kapanpun dan dimanapun sebagai alat pembelajaran multidisiplin. Proses akusisi pengetahuan menjadi lebih efektif dimana pebelajar melakukan eksperimen melalui multimedia simulasi.

Penelitian yang sama dengan penerapan CD pembelajaran dilakukan oleh juga Tsai \& Jenk (2009) yaitu dengan menggunakan quasi-experimental studi dieksplorasi efek dari program Teacher Guided Multimedia CD-ROM sebagai tambahan di pembelajaran siswa mahir vocabulary di EFL. Delapan puluh tujuh siswa SMA di Food and Beverage Management Departement di Universitas Yuanpei Taiwan Utara berpartisipasi dalam studi. Siswa dari dua kelas secara keseluruhan masuk alam kelas kontrol dan kelas eksperimen dalam empat minggu. Penelitian yang terbagi kelas eksperimen dalam dua minggu satu jam sesi menggunakan pengajaran tradisional dan satu jam dengan program pembelajaran Teacher Guided Multimedia CD-ROM. Kelas kontrol hanya menerima dua jam pembelajaran tradisional. Dengan pengajar yang sama untuk kedua kelas pembelajaran tersebut. Hasilya menunjukan kelas yang menggunakan program CD-ROM prestasi belajar English Vocabulary lebih baik dibandingkan pengajaran di kelas tradisional. Kesimpulannya dibahas secara jelas degan perolehan vocabulary.

\section{KESIMPULAN}

Dalam mengembangkan multimedia pembelajaran interkatif diperlukan beberapa tahap penelitian melalui pendekatan Research And Development. Tahapan pengembangan multimedia yang digunakan mengikuti model pengembangan ADDIE (Analysis, Design, Development, Implementation, Evaluation). Tahapan pengembangan produk CD pembelajaran interaktif ini melalui uji validasi dan uji kelompok besar, dan tahapan terakhirnya implementasi dalam pembelajaran. Dari hasil implementasi $C D$ pembelajaran interaktif di dalam kelas terjadi peningkatan sebesar $5,7 \%$ dari membandingkan pembelajaran yang tidak menggunakan media. Dapat disimpulkan dengan pembelajaran menggunakan CD pembelajaran interaktif yang diterapkan pada mata kuliah Workshop dan Pemanfaatan Media terjadi peningkatan minat mahasiswa dalam belajar. Apabila media ini diterapkan pada mata kuliah yang berbasis praktik yang lainnya diharapkan juga terjadi peningkatan minat mahasiswa dalam belajar.

\section{SARAN- SARAN}

Berdasarkan beberapa kesimpulan di atas, maka saran-saran yang bisa dikemukakan antara lain:

\section{Bagi Sekolah}

Perguruan tinggi juga selayaknya sekolah bagi peserta didik untuk mengembangkan kemampuannya, sebagai tempat menuntut ilmu bagi peserta didik alangkah baiknya penunjang 
proses belajar yakni sarana dan prasarana yang lengkap, sesuai dengan standar yang telah ditetapkan Badan Standar Nasional Pendidikan (BSNP).

2. Bagi Dosen

Multimedia pembelajaran ini menjadi contoh sederhana agar bisa dikembangkan untuk mata kuliah dengan basis praktik lainnya.

3. Bagi Peneliti Lain

Pada pengembang berikutnya yang ingin mengembangkan media serupa, diusahakan tampilan multimedianya bisa ditampilakan secara penuh (full screen) diberbagai ukuran layar monitor, hal ini karena media yang dikembangkan ini idealnya hanya untuk ukuran layar monitor 14 inch.

\section{DAFTAR PUSTAKA}

Daryanto \& Bintoro. (2014). Manajemen Diklat. Yogyakarta. Gava Media.

Gunawardhana, L. K. P. D. \& Palaniappan, S. (2016). Possibility of using Multimedia Application for Learning. GSTF Journal on Computing (JOC), 5 (1), pp.77-83.

Hashmi, N. A. (2016). Implementing Multi-Media as a Pedagogical Tool in an EFL Classroom: Benefits and Barriers. Journal of Arts \& Humanities, 5(9), pp.13-22.

Januszewski, A., \& Molenda, M. (2008). Educational Technology. New York: Lawrence Erlbaum Associates.

Kustandi, C \& B. Sujipto. (2011). Media Pembelajaran: Manual dan Digital. Bogor: Ghalia Indonesia.

Kustiono. (2010). Media Pembelajaran: Konsep, Nilai Edukatif, Klasifikasi, Praktek Pemanfaatannya dan Pengembangan. Buku Ajar. Semarang: Unnes Press.

Malik, S., \& Agarwal, A. (2012). Use of Multimedia as a New Educational Technology Tool-A Study". International Journal of Information and Education Technology, 2 (5).

Miarso, Y. (2007). Menyemai Benih Teknologi Pendidikan. Jakarta: Kencana.

Munir. (2008). Kurikulum Berbasis Teknologi Informasi dan Komunikasi. Bandung: CV Alfabeta.

Rusli, M. (2014). The Effect of Two-Dimensional Learning Style on Interactive Multimedia Learning to the Learning Result. International Journal of Computer Applications, 87 (14).

Sadiman, A. S., R. Rahardjo, A. Haryono, \& Rahardjito. (2009). Media Pendidikan: Pengertian, Pengembangan, dan Pemanfaatannya. Jakarta: Rajawali Pers.

Sugiyono. (2010). Metode Penelitian Pendidikan: Pendekatan Kuantitatif, Kualitatif, dan R\&D. Bandung: Alfabeta.

Tsai, R. \& Jenks, M. (2009). Teacher-Guided Interactive Multimedia for Teaching English in an EFL Context. Journal of Educational Multimedia and Hypermedia, 18 (1), pp. 91.

Vaughan, T. (2006). Multimedia: Making It Work Edisi 6. Translated By D. Prabantini. Yogyakarta: Andi.

Warsita, B. (2008). Teknologi Pembelajaran: Landasan dan Aplikasinya. Jakarta: PT Rineka Cipta. 